IVANA POPOVIĆ ${ }^{1}$, JELENA D. RUSMIROVIĆ ${ }^{2}$ MILICA RANČIĆ ${ }^{3}$, ANA TASIĆ ${ }^{4}$, DRAGANA LAZIĆ ALEKSANDAR D. MARINKOVIĆ ${ }^{*}$

${ }^{1}$ University of Belgrade, Faculty of Technology and Metallurgy, Belgrade, Serbia, ${ }^{2}$ University of Belgrade, Innovation center, Faculty of Technology and Metallurgy,Belgrade, Serbia, ${ }^{3}$ University of Belgrade, Faculty of Forestry, Belgrade, Serbia, ${ }^{4}$ Military Technical Institute, Belgrade, Serbia
Scientific paper

ISSN 0351-9465, E-ISSN 2466-2585

UDC: $620.197 .6>620.198$

doi:10.5937/ZasMat1504483P

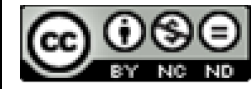

Zastita Materijala 56 (4)

483 - 491 (2015)

\title{
Synthesis of high-performance alkyd anticorrosion coatings based on waste poly(ethylene terephthalate)
}

\begin{abstract}
Synthesis of high-performance anticorrosive coatings obtained from alkyd resins (ARs) based on waste poly(ethylene terephthalate) (PET) glycolyzates is presented. PET glycolyzates, synthesized by catalytic depolymerization with trimethylolpropane (TMP) and dipropylene glycol (DPG), were used as replacement of part of the polyhydroxylic component during the ARs synthesis. The obtained glycolyzates and ARs were analyzed using FT-IR and ${ }^{1} H N M R$ spectroscopy and acid, iodine, and hydroxyl value were determined. Thickness, adhesion, swelling, corrosion, spraying and layering of the synthesized ARs, as well as alkyd coating film were determined in accordance with SRPS EN ISO standards. ARs were produced in high yields and FT-IR and ${ }^{1} N M R$ analysis results confirmed assumed structures. All synthesized ARs show good elasticity, flexibility, adhesion and the gloss values are greater than $85 \%$, and the alkyd coating films based on AR1 and AR3 showed best corrosion results. The most effective dryer catalyst combination was 0.5 wt.\% Ca, 0.03 wt.\%, Co and 0.45 wt.\% Zr.
\end{abstract}

Keywords: Corrosion, Alkyd anticorrosive coatings, PET based anticorrosive coatings.

\section{INTRODUCTION}

Corrosion presents a natural process of chemical material destruction under the internal and external condition influence. This is an exothermic reaction type, at which oxides, sulfides, sulfates, carbonates and chlorides are formed. In this way, from thermodynamic aspect, the metal turns into a more stable state (as in the mineral). The most important internal factors that affect the formation and development of corrosion are: composition, structure, texture and detection of vulnerable seats and outer: pressure, temperature, type and concentration of the environment, radiation and electrical charge [1]. In order to prevent damage due to corrosion, a variety of technologies were developed to protect the material. These technologies have two aspects: theoretical - damage studying

${ }^{*}$ Corresponding author: Aleksandar Marinković

E-mail: marinko@tmf.bg.ac.rs

Paper received: 18. 07. 2015.

Paper accepted: 10. 09. 2015.

Paper is available on the website: www.idk.org.rs/casopis and practical - the protection methods. The purpose of the theoretical aspect of the protection is reflected in the choice of optimal structural materials, protective procedures or systems, the development of new structural materials, development and determining the effectiveness of new protection methods and systems, establishing corrosion behavior of materials, as well as diagnosing damage and corrosion testing mechanisms [2].

Modified alkyd resins (ARs) are increasingly used in the field of surface protection. ARs are a three-dimensional macromolecule of polyester structure formed by reaction of a polyalcohol with polyacids. Originally, the term referred only to polyesters formed by the reaction of glycerol and phthalic acid. Today, this term includes all polyester resins modified by fatty acids. Fatty acids, which are usually used for the modification, include a mixture of fatty acids extracted from industrial and natural oils (sunflower, olive, linseed oil, etc) [3-6]. These resins are viscous and sticky consistency and commonly distributed as $60 \%$ solution in organic solvents. ARs are generally obtained by the esterification reaction, which invoIves react of a diacidic to each other, mono- 
functional acid, and the semi-functioning alcohol in the presence of a catalyst.

Poly(ethylene terephthalate) (PET) belongs to the group of polyester polymers, which are widely present in the process of recycling. Due the presence of the ester functional group, it can be reacted with various reagents, whereby there is a cleavage of the macromolecular chains at the pair oligomeric chains. Materials for a variety of chemical recycling of waste PET can be in the form of a fabric, film, foam, plate, bottle etc. The chemical recycling of PET can be divided into processes of: hydrolysis, alcoholysis, glycolysis, aminolysis and other procedures [7-9].

In this paper, the synthesis of hybrid anticorrosive coating film based on ARs obtained from waste PETglycolyzates is presented. Waste PET was glycolyzed using multifunctional and difunctional alcohols: trimethylolpropane (TMP) and dipropylene glycol (DPG), respectively, and further, the synthesized PET glycolyzates were used as the replacement of a certain amount of alcohols. Derived PET glycolyzates also reduced the amount of phthalic anhydride in the ARs composition, because PET glycolyzate also introduces an aromatic ring. Obtained ARs were used in anticorrosion coating production and the physicalchemical and corrosion characteristics were determined.

\section{EXPERIMENTAL}

\subsection{Materials}

PET was collected from waste packaging. It was flaked into small pieces and washed with a detergent, ethanol and dichloromethane. Dipropylene glycol - a mixture of 4-oxa-2,6-heptandiol, 2-(2-hydroxy-propoxy)-propan-1-ol, and 2-(2-hydroxy-1-methyl-ethoxy)-propan-1-ol (DPG), trimethylolpropane (TMP), pentaerythritol (PE), phthalic anhydride (PA), tetrabutyltitanate (TBT), potassium hydroxide, zinc phosphate and xylene ( $X Y L)$ were obtained from Sigma-Aldrich, and used without any further purification. Dichloromethane (DCM) was purchased from Fluka. $5 \%$ solution of calcium octoate (Ca) and cobalt octoate (Co), as well as 8 $\%$ solution of zirconium octoate $(\mathrm{Zr})$ dissolved in white spirit was used as purchased.

\subsection{PET glycolysis}

a) Glycolysis of PET using multifunctional alcohol - The glycolysis of waste PET was carried out in a $500 \mathrm{ml}$ four-necked flask equipped with a thermometer, nitrogen inlet tube, a reflux condenser and a mechanical stirrer and $1.0 \mathrm{~mol}$ of the PET, $3.0 \mathrm{~mol}$ of TMP and $0.28 \mathrm{ml}(0.3 \mathrm{wt} . \%)$ of TBT polymerization catalyst were charged to the reactor. The reaction mixture was heated at $210^{\circ} \mathrm{C}$ under nitrogen atmosphere for $6 \mathrm{~h}$. After com- pletion of the glycolysis, all reaction mixtures were dissolved in dichloromethane and washed with distilled water in order to remove the excess of alcohols. Afterwards, the mixtures were filtered and dried at $80^{\circ} \mathrm{C}$ for 12 hours.

b) Glycolysis of PET using difunctional alcoholFollowing the procedure of glycolysis method using multifunctional alcohol (method 2.2.a)), new synthesis of PET glycolyzate was done with the difunctional alcohol DPG.

The products of PET glycolysis were named GTMP (method 2.2 a)), and G-DPG (method 2.2 b)).

\subsection{Isolation of fatty acid of linseed oil}

In a four-necked flask of $500 \mathrm{ml}$, equipped with a reflux condenser, mechanical stirrer, thermometer and dropping funnel, the potassium hydroxide solution in ethanol $(30 \%, 0.91 \mathrm{~mol})$ was slowly added dropwise into ethanol solution of 233 $\mathrm{g}$ of linseed oil (LO). The obtained molar ratio of potassium hydroxide/linseed oil was 3.5/1. The reaction mixture was maintained at temperature below $10{ }^{\circ} \mathrm{C}$ for 1 hour, and then the temperature was raised to $50{ }^{\circ} \mathrm{C}$ and held for 2 hours. Twothirds of the solvent were removed by distillation. The resulting pasty residue was dissolved in the required amount of distilled water to get clear solution, and after addition of activated carbon and filtration, the obtained solution was acidified by addition of appropriate volume of $10 \% \mathrm{HCl}$ until pH of 3 was attained. Top layer of linseed oil fatty acids (LFA) was separated; the aqueous layer was extracted twice with $250 \mathrm{ml}$ of diethyl ether and combined with organic layer. The resulting ethereal solution was dried with sodium sulfate. Evaporation of ether by atmospheric distillation was followed by assembling vacuum system which enabled drying and removal of low boiling component of reaction product. Characteristics of LFA: $A V=200 \mathrm{mg}$ $\mathrm{KOH} / \mathrm{g} ; \mathrm{JV}=150 \mathrm{~g} / 100 \mathrm{~g}$.

\subsection{Synthesis of alkyd resins}

a) Synthesis of AR1 resin: After the glycolysis (method $2.2 \mathrm{a})$ ), the reaction mixture was cooled to

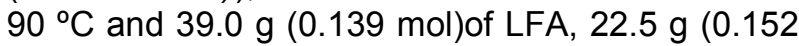
$\mathrm{mol})$ of PA and $16.7(0.123 \mathrm{~mol})$ of PER were added. For the ARs synthesis, a four-necked reactor equipped with a stirrer, thermometer, nitrogen inlet tube and Dean-Stark separator was used. XYL was used as the azeotropic solvent. All ingredients were charged into the reactor and the reaction mixture was heated to $220^{\circ} \mathrm{C}$. A mixture of $5 \mathrm{wt} \%$ $\mathrm{Ca}$ and $\mathrm{Co}$, and $8 \mathrm{wt} \%$ of $\mathrm{Zr}$ was added in the proportion of $1 \mathrm{wt} \%$ as the best drying catalyst system.

b) Synthesis of AR2 resin: In an analogous manner to experiment 2.4. a), AR2 was synthesized from the G-TMP glycolysis product with the following modification: $9.7(0.024 \mathrm{~mol})$ of G-TMP, 
$39.0 \mathrm{~g}(0.139 \mathrm{~mol})$ of LFA, $16.4 \mathrm{~g}(0.111 \mathrm{~mol})$ of PA and $14.4(0.106 \mathrm{~mol})$ of PER.

c) Synthesis of $A R 3$ resin: In an analogous manner to experiment 2.4. b), AR3 was synthesized from the G-DPG glycolysis product (method 2.2. b)).

Table 1 - Reactants amounts used in ARs synthesis

\begin{tabular}{|l|c|l|c|l|c|l|c|}
\hline AR1 & $\mathrm{n}(\mathrm{mol})$ & AR2 & $\mathrm{n}(\mathrm{mol})$ & AR3 & $\mathrm{n}(\mathrm{mol})$ & AR4 & $\mathrm{n}(\mathrm{mol})$ \\
\hline LFA & 0.139 & LFA & 0.139 & LFA & 0.214 & LFA & 0.100 \\
\hline G-TMP & 0.052 & G-TMP & 0.024 & G-DPG & 0.019 & G-DPG & 0.029 \\
\hline PA & 0.152 & PA & 0.111 & PA & 0.108 & PA & 0.189 \\
\hline PER & 0.123 & PER & 0.106 & PER & 0.103 & TMP & 0.204 \\
\hline
\end{tabular}

\subsection{Characterization of the products of glycolysis} and synthesized alkyd resins

The structural analysis of the obtained glycolyzed product and synthesized ARs was performed by FT-IR (Bomem MB-102) spectroscopy, within a range of $400-4000 \mathrm{~cm}^{-1}$, at a resolution of $4 \mathrm{~cm}^{-1}$. ${ }^{1} \mathrm{H}$ and ${ }^{13} \mathrm{C}$ NMR spectra of the glycolyzed products and ARs were recorded in deuterated chloroform $\left(\mathrm{CDCl}_{3}\right)$, using a Varian-Gemini 2000 spectrometer at $200 \mathrm{MHz}$ for the ${ }^{1} \mathrm{H}$ NMR and $50 \mathrm{MHz}$ for the ${ }^{13} \mathrm{C}$ NMR spectra.

The acid value (AV) was determined using a standard method ASTM D3644 [10]. The hydroxyl value $(H V)$ was determined using a conventional acetic anhydride/pyridine method (ISO 4326:1992) [11]. lodine value was determined by the Wijs method.

The flexibility of dry alkyd film was measured according to the ISO 1520 [12] using a cupping tester (Byk PF-5400, BYK-Gardner GmbH, Geretsried, Germany). The adhesion of the films to the substrate was characterized using the crosshatch adhesion method (ASTM D 3359 [13]), which is a simple and effective method for evaluating adhesion. Gloss was measured by a single angle gloss meter (AG-4442, BYK-Gardner $\mathrm{GmbH}$, Geretsried, Germany). All measurements were done at an angle of $60^{\circ}$ (ASTM D 523 [14]). Hardness was measured by a pendulum hardness tester (Byk PH-5858, BYK-Gardner GmbH, Geretsried, Germany) using a König pendulum according to ASTM D 4366 [15].

Thickness, adhesion, swelling, corrosion, spraying and layering of the alkyd anticorrosion Table 2 - The HV and AV values and the results of elemental analysis of the PET glycolyzates

\begin{tabular}{|l|c|c|c|c|c|c|c|}
\hline Glycolyzate & $\begin{array}{c}\mathrm{HV} V_{\text {theor, }} \\
\mathrm{mg} \mathrm{KOH} / \mathrm{g}\end{array}$ & $\begin{array}{c}\mathrm{HV}_{\text {exp }}, \\
\mathrm{mg} \mathrm{KOH} / \mathrm{g}\end{array}$ & $\begin{array}{c}\mathrm{AV}_{\text {exp }}, \\
\mathrm{mg} \mathrm{KOH} / \mathrm{g}\end{array}$ & & $\% \mathrm{C}$ & $\% \mathrm{H}$ & $\% \mathrm{O}^{*}$ \\
\hline G-TMP & 563 & 551 & 7 & Exp. & 59.45 & 8.09 & 32.46 \\
\hline \multirow{2}{*}{ G-DPG } & 282 & 265 & 6 & Calc. & 60.29 & 7.59 & 32.12 \\
\cline { 5 - 8 } & \multirow{2}{*}{$28 x p}$. & 61.23 & 7.65 & 31.12 \\
\hline
\end{tabular}

"The oxygen percent was calculated as the difference to $100 \%$. mixture with major fraction of bis[2-(2-hydro- d) Synthesis of AR4 resin: In an analogous manner to experiment 2.4. c), AR4 was synthesized from the G-DPG glycolysis product (method 2.2. c)) and different amounts of reactants.

The amounts of reactants used in reactions are shown in Table 1.

coating films were measured according to SRPS EN ISO 4628 [16] standard.

\section{RESULTS AND DISCUSSION}

\subsection{Glycolysis of PET with $P G$}

The transesterification reactions of waste PET with TMP and DPG were performed in the presence of TBT catalysts, and the obtained hydroxylterminated products of glycolysis were characterized by determination of the hydroxyl (HV) and acid (AV) values and elemental analysis. During the trans-esterification, chain fragmentation occurs and the formation of the corresponding esters of terephthalic acid with used multifunctional and difunctional alcohol [17]. Various oligoesters (glycolysis products) can be obtained by PET depolymerization using DPG. The waste PET glycolyzates G-DPG present the mixture of isomers: bis[1-(2 hydroxypropoxy) propan-2-yl] terephthalate as a result of transesterification by 4-oxa-2,6heptandiol; bis[2-(1-hydroxypropran-2-yloxy)propyl] terephthalate as a result of transesterification by 2(2-hydroxy-1-methyl-eyhoxy)- propan-1-ol; and the xypropoxy)propyl] terephthalate, minor fraction of bis[1-(1-hydroxypropan)-2-yloxy)propan-2-yl] terephthalate and mixed ester of terephthalic acid as a result of the transesterefication with 2-(2hydroxy-1- methyl-ethoxy)-propan-1-ol [18]. The $H V$ and $A V$ values and the data obtained from elemental analysis of the glycolyzed products are presented in Table 2. 
The results of elemental and HV analysis, compared with the theoretical calculation confirmed that the main products of glycolysis were esters of teraphthalic acid and the used glycols. Higher HV values of G-TMP glycolyzate confirmed that this glycolyzate has more terminally hydroxyl groups than G-DPG where was used difunctional alcohol in glycolysis reaction.

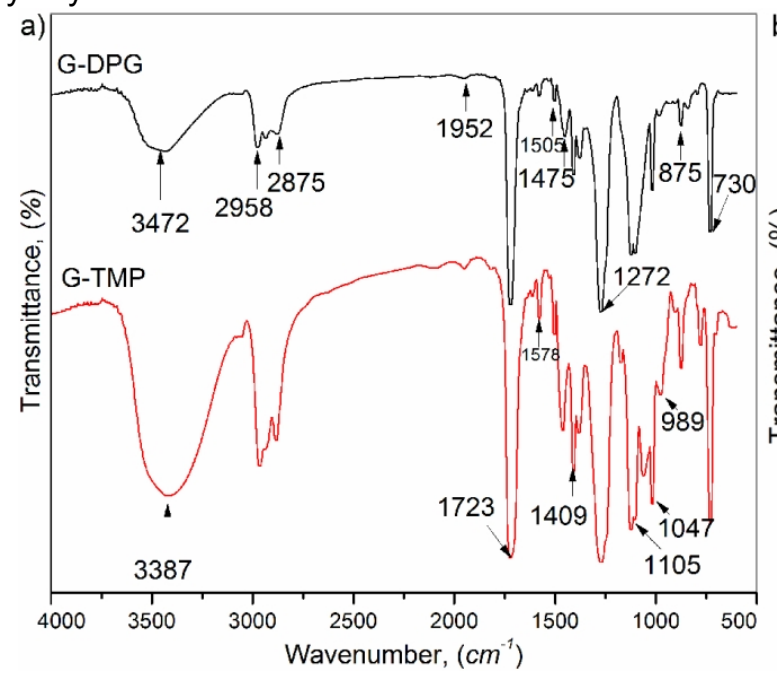

Figure 1 - FT-IR spectra of synthesized a) waste PET glycolyzates and b) ARs

From the FT-IR spectra of the waste PET glycolysis products and synthesized ARs, the broad bands located around $3387 \mathrm{~cm}^{-1}-3472 \mathrm{~cm}^{-1}$ characteristic for the stretching vibration of hydroxyl group can be observed. Difference in the peak intensity originates from the different structures of G-TMP and G-DPG glycolyzates. More intensive peak in this area presented on the FT-IR spectra of G-TMP glycolyzate confirmed presence of higher content of terminal hydroxyl groups than in G-DPG. The aromatic and vinyl $\mathrm{C}-\mathrm{H}$ stretching vibration appears at $3009 \mathrm{~cm}^{-1}$. Overlapping stretching vibrations of methyl and methylene groups (asymmetric and symmetric) are located in the region from 2958 $\mathrm{cm}^{-1}$ to $2875 \mathrm{~cm}^{-1}$ and their corresponding bending vibrations appear at 1459 and $1385 \mathrm{~cm}^{-1}$. The intensive stretching vibration around $1723 \mathrm{~cm}^{-1}$ $1727 \mathrm{~cm}^{-1}$ of the ester carbonyl group appeared. Very strong band from the stretching vibrations of C-O in ester group appeared round $1268 \mathrm{~cm}^{-1}$. Bands that occurs around $970 \mathrm{~cm}^{-1}-989 \mathrm{~cm}^{-1}$ corresponds to the $\mathrm{C}=\mathrm{C}$ skeletal stretching vibration of the benzene ring. Band at around $730 \mathrm{~cm}^{-1}$ is assigned to the vibration of the benzene ring [17].

Results of the ${ }^{1} \mathrm{H}$ and ${ }^{13} \mathrm{C}$ NMR analysis of the G-TMP (exp. 2.2a) are: ${ }^{1} \mathrm{H}$ NMR $\left(\mathrm{CDCl}_{3}\right): 1.02-1.45$ $\left(m, 12 \mathrm{H}, 4 \times \mathrm{XCH}_{3}\right), 3.17-3.88\left(m, 10 \mathrm{H}, 4 \times \mathrm{CH}_{2}\right.$ and $2 \times \mathrm{CH}), 4.10-4.48\left(m, 4 \mathrm{H}, 2 \times \mathrm{COOC}_{2}\right), 8.08(\mathrm{~s}, 4 \mathrm{H}$, $\mathrm{H}_{\mathrm{Ph}}$ );

${ }^{13} \mathrm{C} \mathrm{NMR}\left(\mathrm{CDCl}_{3}\right): 16.2$ and $19.6\left(4 \times \mathrm{CH}_{3}\right), 66.2-$ $78.4\left(4 \mathrm{xCH}_{2}\right.$ and $\left.4 \times \mathrm{CH}\right), 129.6\left(4 \times \mathrm{x}_{\mathrm{Ph}}\right), 133.8$ (2xPh() $-\mathrm{COO}), 164.9$ (2xCOO).

\subsection{Characterization of PET glycolyzates and ARs - NMR and FT-IR analysis}

Analysis of FTIR spectra of the obtained glycolized products and ARs gave information about the functional groups and confirmed their structure. FT-IR spectra of waste PET glycolyzates and ARs are shown in Figure 1.

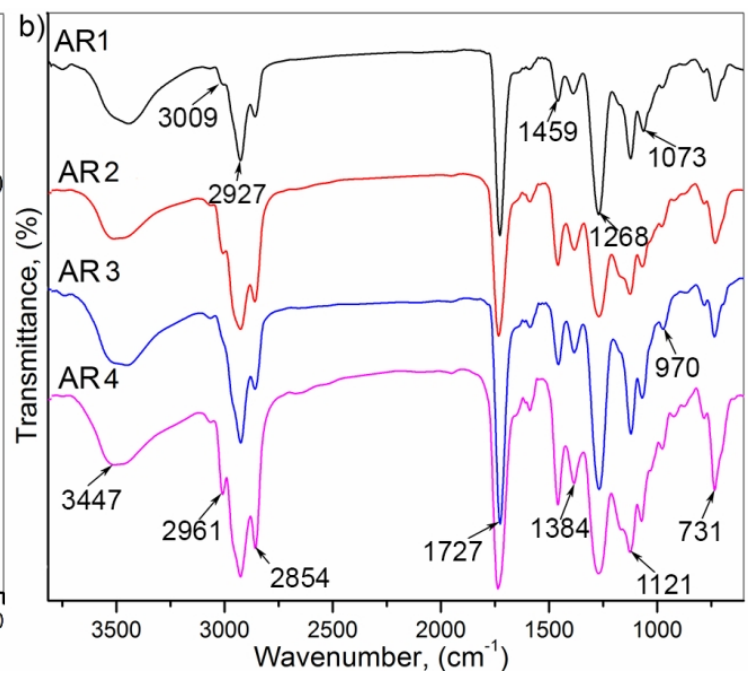

Results of the $1 \mathrm{H}$ and $13 \mathrm{C}$ NMR analysis of the G-DPG (exp. 2.2b) are: ${ }^{1} \mathrm{H}$ NMR: $0.87(m, 6 \mathrm{H}$, $\left.2 \times \mathrm{CH}_{3}\right) ; 3.61\left(m, 8 \mathrm{H}, 4 \times \mathrm{CH}_{2} \mathrm{OH}\right) ; 3.73(m, 4 \mathrm{H}$, $\left.4 \times \mathrm{CH}_{2} \mathrm{OH}\right) ; 4.28-4.51\left(\mathrm{~m}, 8 \mathrm{H}, 4 \times \mathrm{COOCH}_{2}, \mathrm{TME}\right.$ and EG moiety); $7.20\left(m, 2 \mathrm{H}, \mathrm{H}_{\mathrm{Ph}}\right) ; 7.85-8.09(\mathrm{~m}$, $\left.6 \mathrm{H}, \mathrm{H}_{\mathrm{Ph}}\right)$.

${ }^{13} \mathrm{C}$ NMR: $7.50\left(2 \times \mathrm{CH}_{3}\right), 22.74\left(\mathrm{CH}_{3} \underline{\mathrm{CH}}_{2}\right) ; 43.02$ $\left(\mathrm{C}\left(\mathrm{CH}_{2} \mathrm{CH}_{3}\right)\left(\mathrm{CH}_{2} \mathrm{OH}\right)_{2}\left(\mathrm{CH}_{2}\right)\right) ; \quad 65.16 \quad\left(\mathrm{COOC} \mathrm{H}_{2}\right.$, TME moiety); 76.38-77.65 (COOC $\mathrm{CH}_{2}$, EG moiety); $129.78\left(4 \times \mathrm{C}_{\mathrm{Ph}}\right) ; 133.79(2 \times \mathrm{Ph}(\underline{\mathrm{C}}) \mathrm{COO}) ; 165.83$ $(2 \times \underline{\mathrm{COO}})$.

NMR analysis of the G-DPG revealed the existence of mixture of oligoesters as a result of transesterification reactions by DPG mixture [18]. ${ }^{1} \mathrm{H}$ and ${ }^{13} \mathrm{C}$ NMR spectra of G-DPG are shown in Figure 2.

Results of the ${ }^{1} \mathrm{H}$ NMR analysis of the synthesized anticorrosive alkyd resins are:

AR1: ${ }^{1} \mathrm{H}$ NMR $\left(200 \mathrm{MHz}, \mathrm{CDCl}_{3}\right): \delta=0,75-1,06$ (m, 9H, CH3), 1,18-1,42 (s, 23H, $\left.\mathrm{CH}_{2}\right), 1,47-1,77$ (s, $\left.5 \mathrm{H}, \mathrm{CH}_{2}\right), 1,88-2,16\left(\mathrm{~m}, 6 \mathrm{H},=\mathrm{CHCH}_{2}\right), 2,21-$ $2,39\left(\mathrm{~m}, 4 \mathrm{H}, \mathrm{CH}_{2} \mathrm{COOCH}_{2}\right), 2,62-2,86(\mathrm{~m}, 4 \mathrm{H}$, $\left.=\mathrm{CHCH}_{2} \mathrm{CH}=\right), 3,42-3,74\left(\mathrm{~m}, 2 \mathrm{H}, \mathrm{PACOOCH}_{2} \mathrm{i}\right.$ alkilCOOCH$\left.{ }_{2}\right), 4,03-4,74\left(\mathrm{~m}, 9 \mathrm{H}, \mathrm{TPACOOCH}{ }_{2}\right)$, 5,24-5,49 (d, 7H, $-\mathrm{CH}=\mathrm{CH}-), 6,90-7,82(\mathrm{~d}, 4 \mathrm{H}$, PAH), 7,92-8,08 (d, 1H, TPAH) ppm;

Due to the similarity of the corresponding ${ }^{1} \mathrm{H}$ and ${ }^{13} \mathrm{C}$ NMR spectra of other resin based on the G-TMP (AR2), the results are not presented. 


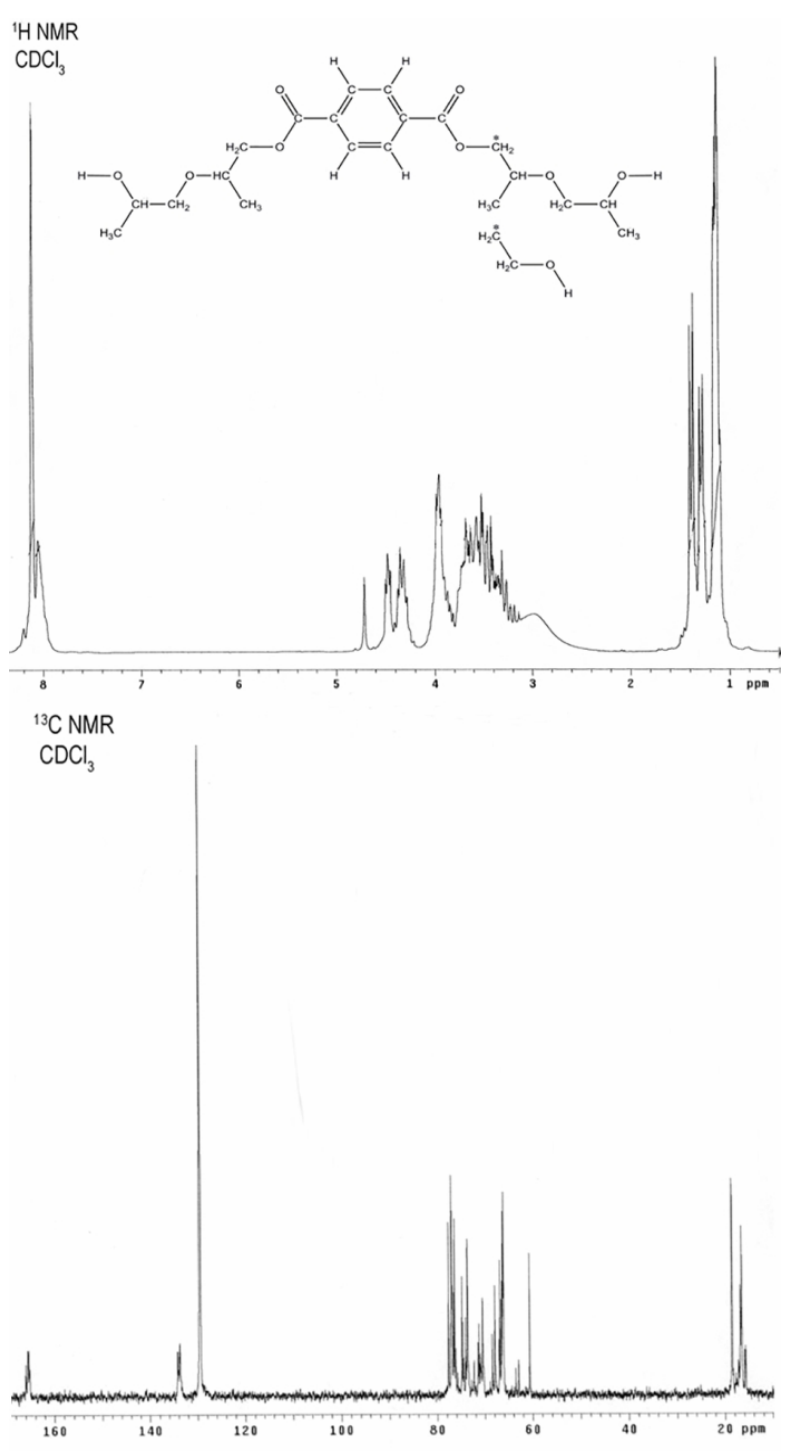

Figure $2-{ }^{1} \mathrm{H}$ and ${ }^{13} \mathrm{C}$ NMR spectra of G-DPG

AR3: ${ }^{1} \mathrm{H}$ NMR $\left(200 \mathrm{MHz}, \mathrm{CDCl}_{3}\right): \delta=0,84-1,04$ (m, 9H, $\left.\mathrm{CH}_{3}\right), 1,11-1,42$ (s, 23H, $\left.\mathrm{CH}_{2}\right), 1,46-1,74$ (s, $\left.5 \mathrm{H}, \mathrm{CH}_{2}\right), 1,81-2,14\left(\mathrm{~m}, 6 \mathrm{H},=\mathrm{CHCH}_{2}\right), 2,21-$ 2,38 $\left(\mathrm{m}, 4 \mathrm{H}, \quad \mathrm{CH}_{2} \mathrm{COOCH}_{2}\right), 2,68-2,87(\mathrm{~d}, 4 \mathrm{H}$, $\left.=\mathrm{CHCH}_{2} \mathrm{CH}=\right), 3,45-3,78\left(\mathrm{~m}, 2 \mathrm{H}, \mathrm{PACOOCH}_{2} \mathrm{i}\right.$ alkil $\left.\mathrm{COOCH}_{2}\right), 4,04-4,76\left(\mathrm{~m}, 9 \mathrm{H}, \mathrm{TPACOOCH}{ }_{2}\right)$, 5,22-5,46 (d, 7H, - $\mathrm{CH}=\mathrm{CH}-), 7,38-7,84 \quad(\mathrm{~d}, 4 \mathrm{H}$, PAH) $, 7,92-8,16$ (d, $1 \mathrm{H}$, TPAH) ppm $;{ }^{1} \mathrm{H}$ and ${ }^{13} \mathrm{C}$ NMR spectra of AS3 based on G-DPG are shown in Figure 3.

Due to the similarity of the corresponding ${ }^{1} \mathrm{H}$ and ${ }^{13} \mathrm{C}$ NMR spectra of other resin based on the G-DPG (AR4), the results are not presented.

The acid value of the synthesized anticorrosive alkyd resins is less than $10 \mathrm{mg} \mathrm{KOH} / \mathrm{g}$ of resin (Table 3). Low acid value indicates that the reaction was conducted long enough for the high reaction degree which is necessary to obtain satisfactory mechanical characteristics of the resin. The highest reaction degree was reached in the synthesis of AR1 and AR3 using G-TMP and GDPG, respectively. lodine value amounts are in range 45-106 (Table 2). The highest iodine value is observed for AR3 with the highest amount of LFA, because iodine number depends on unsaturation which is present in flaxseed oil. Decrease in the LFA amount in the ARs proscription cause a decrease in iodine value of ARs. The HV decrease with the decreasing of amount of hydroxylterminated glycolysis products used for ARs synthesis. The highest HV is observed for AR1 in which synthesis was used the highest amount of multifunctional G-TMP.
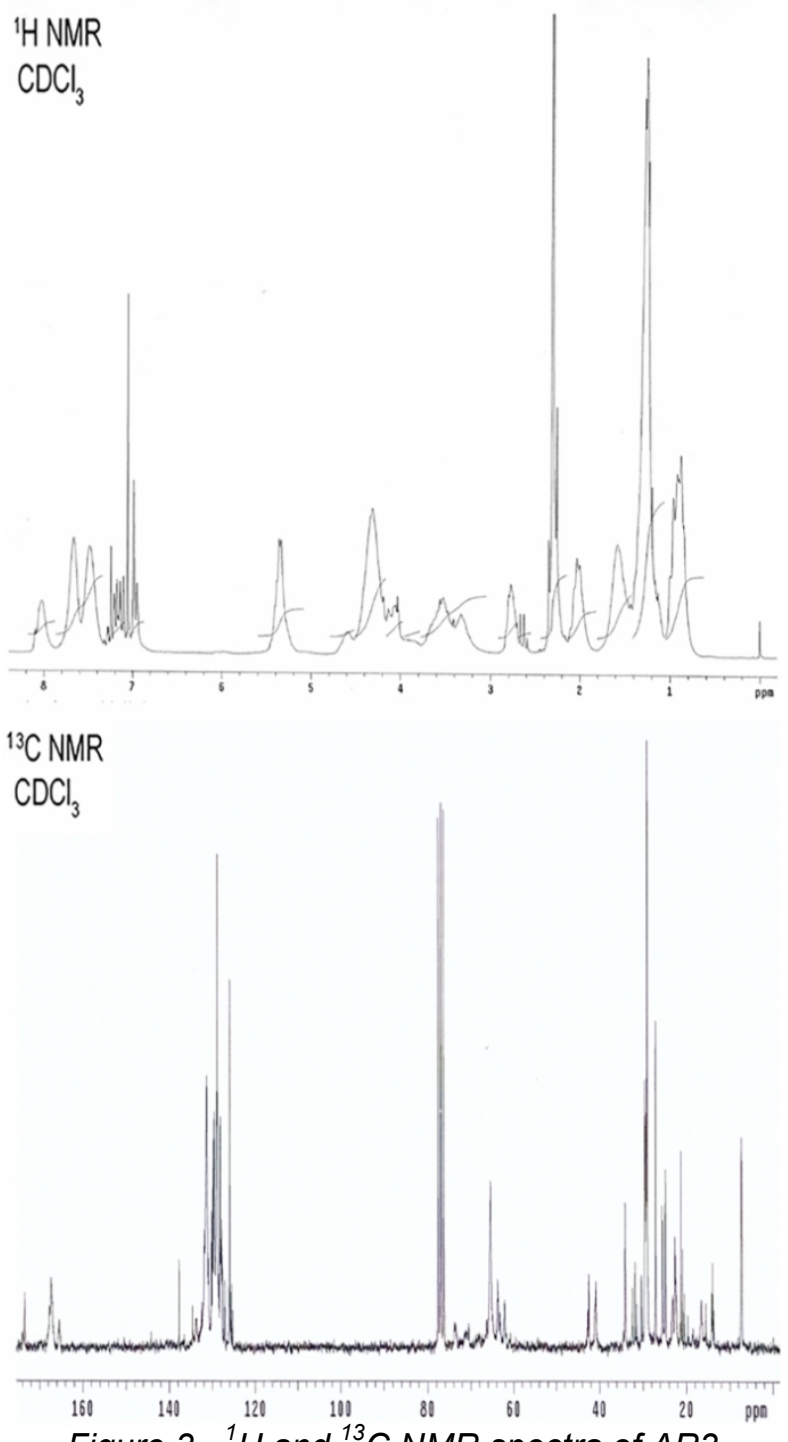

Figure $3-{ }^{1} \mathrm{H}$ and ${ }^{13} \mathrm{C}$ NMR spectra of $A R 3$

Table 3 - Acid value, hydroxyl value and iodine value of the synthesized ARs

\begin{tabular}{|l|c|c|c|c|}
\hline & AR1 & AR2 & AR3 & AR4 \\
\hline $\begin{array}{l}\text { Acid value, } \\
\mathrm{mg}(\mathrm{KOH}) / \mathrm{g}\end{array}$ & 7.0 & 8.5 & 7.3 & 8.0 \\
\hline lodine value, g/100g & 84.6 & 93.0 & 106.6 & 45.1 \\
\hline $\begin{array}{l}\text { Hydroxyl value } \mathrm{mg} \\
(\mathrm{KOH}) / \mathrm{g}\end{array}$ & 64.3 & 43.5 & 19.5 & 23.0 \\
\hline
\end{tabular}


Table 4 shows that major amount of LFA, the largest molar mass has AR1 and the greatest functionality has AR1 and AR4. The greatest alkyd constant, the biggest dry residue share and the largest content of removed water has AR4. Hydrolysis reaction yields are quite high, over $90 \%$.

Table 4 - Molar mass, length of oil, functionality, yield, removed water, alkyd constant and dry residue of anticorrosive alkyd resins

\begin{tabular}{|l|c|c|c|c|}
\hline & AR1 & AR2 & AR3 & AR4 \\
\hline Molar mass, g/mol & 2959.7 & 2662.7 & 3512.1 & 1628.3 \\
\hline Length of oil, \% & 40.56 & 60.79 & 61.19 & 30.91 \\
\hline Alkyd constant & 1.05 & 1.04 & 1.03 & 1.09 \\
\hline Functionality & 1.95 & 1.91 & 1.90 & 1.93 \\
\hline Removed water, \% & 27.4 & 19.9 & 19.5 & 34.1 \\
\hline Dry residue, \% & 74.4 & 81.3 & 85.6 & 90.5 \\
\hline Yield, g & 98.05 & 90.59 & 96.15 & 98.90 \\
\hline
\end{tabular}

\subsection{Dry film properties}

In order to investigate the effect of the functionality and the structure of the obtained glycolyzates on the properties, ARs were exploited in form of the dried film. The alkyd resins were applied by a wire-wound applicator (wet thickness of $100 \mu \mathrm{m}$ ) on mild steel $15 \mathrm{~cm} \times 10 \mathrm{~cm}$ panels for evaluating flexibility, gloss and adhesion and $10 \mathrm{~cm}$ $\times 10 \mathrm{~cm}$ glass panels for evaluating hardness, thickness, elasticity of the extension, flexibility and adhesion. Due to the large percentage of oil content, the drying process of alkyd resins is very slow. In order to solve this problem effectively, the different amounts of the drying catalyst were used in combination with ARs (Table 5). All amounts of the drying catalyst are given in percentages calculated on the total amount of ARs. The coatings were left to dry for 21 days at room temperature prior to the measurements.

Table 5 - Different amounts of drier catalyst

\begin{tabular}{|c|c|c|c|c|}
\hline $\begin{array}{c}\text { Drying } \\
\text { catalyst }\end{array}$ & Comb.1 & Comb. 2 & Comb. 3 & Comb. 4 \\
\hline $\mathrm{Ca}(\%)$ & 0.2 & $/$ & 0.3 & 0.5 \\
\hline $\mathrm{Co}(\%)$ & 0.03 & 0.03 & 0.03 & 0.03 \\
\hline $\mathrm{Zr}(\%)$ & $/$ & 0.3 & $/$ & 0.45 \\
\hline
\end{tabular}

The best result gave siccative combination 4 $(0,5 \% \mathrm{Ca}, 0,03 \%$ Co and $0,45 \% \mathrm{Zr})$ for all synthesized ARs. In order to compare the obtained results, Figure 4 shows the appearance of alkyd coating film in case of driers Comb. 1 (Fig. 4 a)) and the driers Comb. 4 (Fig. 4 b)) after drying. From the Figure $4 \mathrm{a}$ ), it can be seen that, after drying in case of Comb. 1 along the edges a very pronounced effect "orange peel" occurs, and there are freckles along film without shooting.
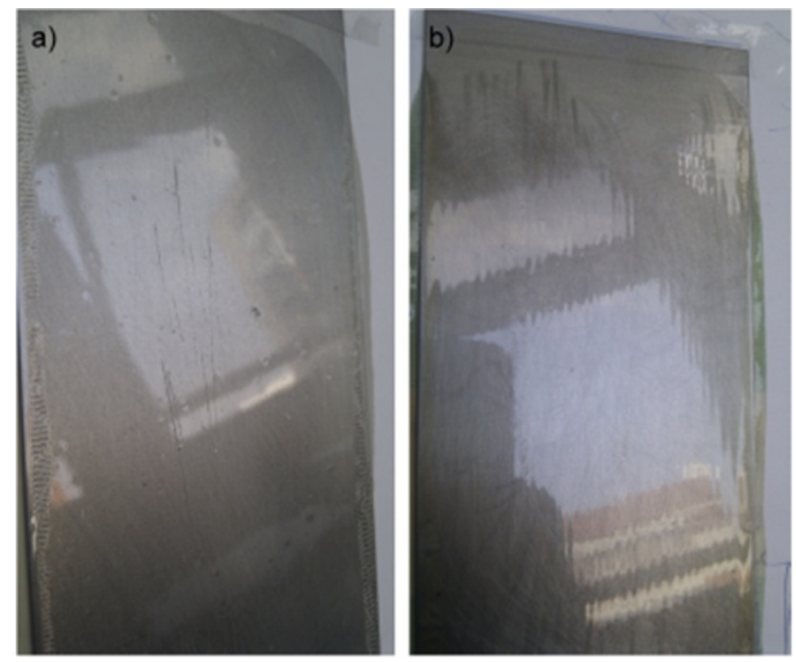

Figure 4 - AR1 with driers combination: a) $0.2 \% \mathrm{Ca}$, $0.03 \%$ Co; b) $0.5 \% \mathrm{Ca}, 0.03 \%$, Co and $0.45 \% \mathrm{Zr}$

ARs molar mass, the amount of LFA and reactants with ring structure mostly affect the hardness of the dry ARsfilm.Thickness, hardness, elasticity flexibility and adhesion test results of ARs are shown in Table 6.

Table 6 - Dry film thickness, Köning hardness, the elasticity of the extension, flexibility and adhesion over the mandrel of ARs

\begin{tabular}{|c|c|c|c|c|c|}
\hline Resin & $\begin{array}{c}\text { Thickness, } \\
\mu \mathrm{m}\end{array}$ & $\begin{array}{c}\text { Hardness, } \\
\mathrm{sec}\end{array}$ & $\begin{array}{c}\text { Elasticity, } \\
\mathrm{mm}\end{array}$ & $\begin{array}{c}\text { Flexibility, } \\
\varnothing 6 \mathrm{~mm}\end{array}$ & $\begin{array}{c}\text { Adhesion, } \\
\text { 0-good 4-bad }\end{array}$ \\
\hline AR1 & 23 & 89 & 10 & OK & 0 \\
\hline AR2 & 15 & 76 & 10 & OK & 0 \\
\hline AR3 & 20 & 86 & 10 & OK & 0 \\
\hline AR4 & 12 & 37 & 10 & OK & 0 \\
\hline
\end{tabular}


Table 6 shows that the dry film thickness ranges from 12 to $23 \mu \mathrm{m}$. Such variation in the thickness of the film is likely the result of a variety of dry matter and molar mass. The hardness of alkyd coating films increases with the increasing of ARs molar mass which is conditioned by configuration of the reactant used in synthesis. The highest hardness value was obtained for the AR1 dry film with incorporation of multifunctional alcohol (TMP), while lower value of 86 was obtained for the AR3 dry film with incorporation of high amount of difunctional alcohol and LFA. The measured Köning hardness varies considerably, ranging from 37 to 89 seconds. The highest value revealed alkyd resins AR1 andAR3 which showed significantly higher hardness than commercial resins. The measured values for elasticity, flexibility and adhesion are small maximum value for all samples.

Gloss is the ability of surfaces to reflect incident light in one direction. Table 7 shows that all synthesized resins have a high gloss, greater than $94 \%$. This occurs at extremely high gloss resin that totally refuses: light rays and sometimes causes interference and amplification of waves.
Table 7 - Gloss values of synthesized ARs

\begin{tabular}{|l|l|}
\hline Resin & Gloss $\left(\alpha=60^{\circ}\right)$ \\
\hline AR1 & $94.0 \%$ \\
\hline AR2 & $93.2 \%$ \\
\hline AR3 & $85.0 \%$ \\
\hline AR 4 & $99.7 \%$ \\
\hline
\end{tabular}

\subsection{Anticorrosion properties of the obtained dry AR coating films}

Investigated alkyd anticorrosion coatings (Figure 5) were composed of synthesized ARs (30 wt.\%), zinc phosphate (20 wt.\%) and the filler. Zinc phosphate and fillers were mixed with ARs in the per-mill. The appearance of dry ARs anticorrosion coating films based on AR1 (Co-AR1), AR2 (CoAR2), AR3 (Co-AR3) and AR4 (Co-AR4) after anticorrosion analysis are shown on Figure 5.

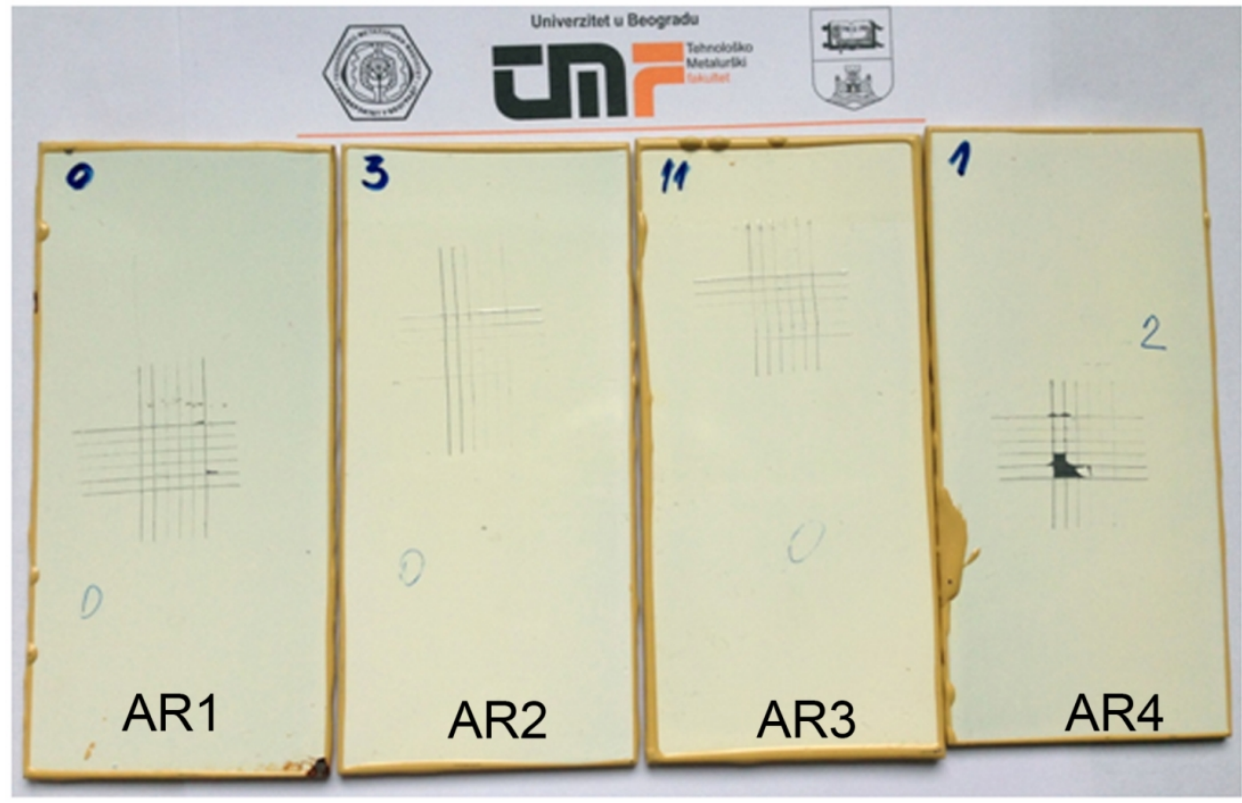

Figure 5 - Dry ARs anticorrosion coating films based on a) AR1 (Co-AR1), b) AR2 (Co-AR2), c) AR3 (Co$A R 3)$ and d) AR4 (Co-AR4) after anticorrosion analysis

Thickness, adhesion test results, swelling, corrosion, spraying and layering of untreated plate in a humid and salt chamber are shown in Tables 8 and 9, respectively.

Table 8 -Thickness, adhesion, swelling, corrosion, spraying and layering of ARs coating in a humid chamber

\begin{tabular}{|c|c|c|c|c|c|}
\hline Coating film & $\begin{array}{c}\text { Thickness, } \\
\mu \mathrm{m}\end{array}$ & $\begin{array}{c}\text { Adhesion, } \\
\text { 0-good 5-bad }\end{array}$ & $\begin{array}{c}\text { Swelling, } \\
\text { 0-good 5-bad }\end{array}$ & Corrosion & $\begin{array}{c}\text { Spraying } \\
\text { 0-good 5-bad }\end{array}$ \\
\hline Co-AR1 & 102 & 1 & 0 & Ri0 & 0 \\
\hline Co-AR2 & 189 & 5 & 0 & Ri0 & 0 \\
\hline Co-AR3 & 192 & 1 & 0 & Ri0 & 0 \\
\hline Co-AR4 & 168 & 5 & 0 & Ri0 & 0 \\
\hline
\end{tabular}


Table 9 - Thickness, adhesion, swelling, corrosion, spraying and layering of ARs coating in a salt chamber

\begin{tabular}{|c|c|c|c|c|c|}
\hline Coating film & $\begin{array}{c}\text { Thickness, } \\
\mu \mathrm{m}\end{array}$ & $\begin{array}{c}\text { Adhesion, } \\
\text { 0-good 5-bad }\end{array}$ & $\begin{array}{c}\text { Swelling, } \\
\text { 0-good 5-bad }\end{array}$ & Corrosion, & $\begin{array}{c}\text { Spraying } \\
\text { 0-good 5-bad }\end{array}$ \\
\hline Co-AR1 & 190 & 1 & 0 & Ri0 & 0 \\
\hline Co-AR2 & 103 & 5 & 0 & Ri0 & 0 \\
\hline Co-AR3 & 193 & 1 & 0 & Ri0 & 0 \\
\hline Co-AR4 & 170 & 1 & 0 & Ri0 & 0 \\
\hline
\end{tabular}

Thickness of dry anticorrosive film ranges from 105 to $193 \mu \mathrm{m}$. Comparing anticorrosion test results of untreated ARs coating films in a humid and salt chamber, it can be concluded that the CoAR1 and Co-AR3 films satisfy the requirements of the prescribed quality standards.

\section{CONCLUSION}

This study investigated the uses possibility of waste PET in the production of anticorrosive alkyd coatings. Presented ARs were prepared by reacting of PET glycolizates, synthesized by trans-esterification reactions of waste PET and multifunctional alcohol TMP, as well as, difunctional alcohol DPG, with PER, PA and LFA. From the physical-mechanical test results, it can be concluded that properties of the ARs are highly dependent on the functionality and the structure of the employed glycolyzates, as well as amount of used reactants, especially of LFA amount. ARs with better properties were derived from the multifunctional glycolyzates and the higher amount of LFA. Hardness values increase with the increasing of ARs molar mass and depend on the amount of fatty acids (i.e. the cross-linking degree) and the reactants with ring structure. Also, this ARs show good elasticity, flexibility, adhesion and the gloss values are greater than $85 \%$. All ARs were produced in high yields and FT-IR and NMR spectra confirmed their structures. All those results indicate that waste PET can be used for synthesis of anticorrosive alkyd coatings with good characteristics.

\section{Acknowledgements}

The authors acknowledge financial support from Ministry of Education, Science and Technological development of Serbia, Project Nos. OI 172057.

\section{REFERENCES}

[1] M.A.Malik, M.A.Hashim, F.Nabi, S.A.AL-Thabaiti, Z.Khan (2011) Anti-corrosion ability of surfactants: A Review, International Journal of Electrochemical Science, 6, 1927-1948.

[2] P.Marcus, V.Maurice (2009) Fundamental aspects of corrosion of metallic materials, Book Material Science and Engineering - Volume 1, Encyclopedia of Life Support Systems, USA, 99-133.

[3] O.Saravari, P.Phapant, V.Pimpan (2005) Synthesis of water-reducible acrylic-alkyd resins based on modified palm oil, Journal of Applied Polymer Science, 96, 1170-1175.
[4] C.F.Uzoh, O.D.Onukwuli, R.S.Odera, C.F.OkeyOnyesolu (2013) Synthesis and characterization of palm oil based air drying alkyd resin for surface coating, Research Journal in Engineering and Applied Sciences, 2, 187-191.

[5] I.Martínez San Segundo (2014) Synthesis of novel alkyd binders for protective wood coatings from biobased raw materials, Doctorial Thesis, Technical University of Denmark.

[6] G.Oladipo, I.Eromosele, O.Folarin (2013) Formation and characterization of paint based on alkyd resin derivative of ximenia americana (Wild Olive) seed Oil, Environment and Natural Resources Research, 3(3), 52-62.

[7] P.Karayannidis, S.Achilias, D.Sideridou, N.Bikiaris (2005) Alkyd resins derived from glycolized waste poly(ethylene terephthalate), European Polymer Journal, 41, 201-210.

[8] G.Güçlü, M.Orbay (2009) Alkyd resins synthesized from postconsumer PET bottles, Progress in Organic Coatings, 65, 362-365.

[9] L.Bartolome, M.Imran, B.G.Cho, W.Al-Masry, D.H.Kim (2012) Recent developments in the chemical recycling of PET, Book Material Recycling - Trends and Perspectives, InTech, 65-84.

[10] ASTM D1957-86R01 (2014) Test Method for Hydroxyl Value of Fatty Oils and Acids.

[11] ASTM D1639 (2014) Test Method for Acid Value of Organic Coating Materials.

[12] ISO 1520 (2006), Paints and varnishes -Cupping test.

[13] ASTM D 3359 (2002) Standard Test Methods for Measuring Adhesion by Tape Test.

[14] ASTM D 523 (2014) Standard Test Method for Specular Gloss.

[15] ASTM D 4366 (2014) Standard Test Methods for Hardness of Organic Coatings by Pendulum Damping Tests.

[16] SRPS EN ISO 4628 (1998) Paints and varnishes Evaluation of degradation of coatings - Designation of quantity and size of defects, and of intensity of uniform changes in appearance.

[17] P.Spasojević, V.Panić, J.Džunuzović, A.Marinković, A.Woortman, K.Loosd, I.Popović (2015) High performance alkyd resins synthesized from postconsumer PET bottles, RSC Advances, 5, 62273-62283.

[18] J.Rusmirović, T.Radoman, E.Džunuzović, J.Džunuzović, J.Markovski, P.Spasojević, A.Marinković (2015) Effect of the modified silica nanofiller on the mechanical properties of unsaturated polyester resins based on recycled polyethylene terephthalate, Polymer Composites, in press. 


\section{IZVOD}

\section{SINTEZA VISOKOEFIKASNIH ALKIDNIH ANTIKOROZIONIH PREMAZA NA BAZI POLI(ETILEN TEREFTALATA)}

$U$ radu je prikazana sinteza visokoefikasnih antikorozivnih premaza dobijenih iz alkidnih smola (AR) baziranih na proizvodima glikolize iz otpadnog poli(etilen tereftalata) (PET). Glikolizati PET-a dobijeni postupkom katalitičke depolimerizacije uz pomoć trimetilolpropana (TMP) $i$ dipropilen glikola (DPG), su korišćeni kao zamena polihidroksilne komponente tokom sinteze AR smola. Sintetisani glikolizati i AR smole okarakterisane su primenom FT-IR $i{ }^{1} H N M R$ spektroskopije $i$ određena im je vrednost kiselinskog, jodnog i hidroksilnog broja. Sintetisanim AR smolama, kao $i$ antikorozionim alkidnim premazima određena su sledeća svojstva: debljina suvog filma, adhezivnost, bubrenje, korozivnost, prskanje i odslojavanje prema SRPS EN ISO standardima. Alkidne smole su dobijene $u$ visokom prinosu i pokazale su dobra fizičko-mehanička svojstva, adhezivnost $i$ sjaj premaza ( $\leq 85 \%)$, dok su antikorozioni alkidni premazi na bazi AR1 $i$ AR3 pokazali najbolje rezultate otpornosti na koroziju. Najefikasnija kombinacija katalizatora sušenja je 0.5 mas. \% Ca, 0.03 mas. \%, Co i 0.45 mas\% Zr.

Ključne reči: korozija, alkidni antikorozioni premazi, antikorozioni premazi na bazi PET-a

Naučni rad

Rad primljen 18. 07. 2015.

Rad prihvaćen 10. 09. 2015.

Rad je dostupan na sajtu: www.idk.org.rs/casopis 